\title{
XXXVI. Observations on the combination of metals with sulphur
}

\section{M.A.J. Frere de Montizon}

To cite this article: M.A.J. Frere de Montizon (1817) XXXVI. Observations on the combination of metals with sulphur, Philosophical Magazine Series 1, 49:226, 143-144, DOI:

$10.1080 / 14786441708637863$

To link to this article: http://dx.doi.org/10.1080/14786441708637863

册 Published online: 27 Jul 2009.

Submit your article to this journal $\sqsubset \pi$

Џ Article views: 2

Q View related articles $\asymp$ 
this treatment of blue flame, and various shades of yellow, \&c. with green flame. I shall only observe in the meantime, I think it very probable that the rolour of farne, and particularly of the lamina or border (which in that of sulphuret of carbon is a fine blue) with its (the edge) width, will determine the grade of ignition; and it is my opinion that all flames have a decided electrical character, which will express their relation to the intensities of ignition.

Oxygen compresserl in Newman's blowpipe and passed through the flame of sulphuret of carbon produces a much more violent. heat, than when alcohol is sulstituted as in Dr. Marcet's experiment.

I have lately made but few experiments with the compressed gases in the blowpipe. I lowever repeated successfully Dr. Clarke's experiment with the rubies; I also fuser Two sAPP'HIRES into ONE. In one instance I completely perforated the stem of a tolacco-pipe, which the jet of inflamed gases vitrified in its passage, - a steel file before it, literally, as Dr. Clarke expresses it, presents "a shower of fire." In this experiment it is adviseable to detach the bladder containing the mixed gases, lest the sparks should ignite the explosive volume.

I am respectfully, sir,

Your humble servant,

Surry Institution, Teb. 20, 1817.

J. Murray.

P.S. It should be stated, that when the red-hot platinum wire is introduced into a wine-glass containing sulphuret of carbon, it alwars kindles the fluid; but it will be seen to continue red hot between the surface of the fluid and the base of the flame.

When oil is used in the cell of the blowpipe it has this disadvantage: the ebullition is distinguished with muck difficuty by the car; but when water is employed, the bubbling is very audible, and the latter is therefore a less equivocal index of safety. J.M.

XXXVI. Olservations on the Combination of Metals with Sulphatr. By M.A.J. Frene de Montizon *.

A particular examination which I have made of cinnabar, leads me to suppose that this sulphuret results from the combination of a volune of mercury and another of sulphur : but in order to confirm my opinion in the most positive mamer, I have endearoured to ascertain whether this mode of composition bc also that of other sulphurets.

On this subject I have had recourse to the analyses generally

* Irom the Anualcs de Chimie et de Physinue, for Septerlar 1816. adopted, 
adopted, and fixed my attention to these alone, as calculated to inspire more confidence in this sort of investigation.

The results which I have obtained confirmed my remark, by some thousandth parts of sulphur in 100 parts of mass. Cinnabar offers the greatest difference:-according to Berzelius I have found about a hundredth of sulphur in 100 parts in weight ; and according to Seguin it is less by half a hundredth.

As my experinents on this Gecasion may possess some interest on account of science, I have veliturcd to offer the following table of sulphurets.

\begin{tabular}{|c|c|c|c|c|c|c|}
\hline \multirow{3}{*}{ Sulphurets. } & \multirow{3}{*}{$\begin{array}{l}\text { Authors } \\
\text { of the } \\
\text { Analyses. }\end{array}$} & \multirow{3}{*}{$\begin{array}{c}\text { Density } \\
\text { of the } \\
\text { Metals. }\end{array}$} & \multicolumn{2}{|c|}{ Quantity of Metal. } & \multirow{2}{*}{\multicolumn{2}{|c|}{$\begin{array}{c}\text { Reduction of } \\
\text { volumes. }\end{array}$}} \\
\hline & & & In weight & In volume & & \\
\hline & & & $=20$ & $=10,05$ & Sulphur. & Metals. \\
\hline Of Mercury & Berzelius & 13.599 & $125 \cdot 5$ & $9 \cdot 227$ & $1 \cdot$ & 1 or 0.918 \\
\hline - Mercury & Sieguin & 13.599 & 131.26 & $9.65 ?$ & 1. & $i-0.90$ \\
\hline- Tin & Berzelius & $7 \cdot 291$ & $73 \cdot 5$ & $10 \cdot 081$ & 1 . & $1-1 \cdot 005$ \\
\hline - Nickel & Proust & 8.279 & 40.53 & $5 \cdot 140$ & 2. & $1-1 \cdot 000$ \\
\hline - Arsenic & Inugier & 8.308 & 27.62 & $5 \cdot 324$ & 3. & $1-0.993$ \\
\hline - Molybdenum & Bucholz & $7 \cdot 44)$ & 30 & $4 \cdot() j=$ & 5. & $2-2.013$ \\
\hline$-\operatorname{Zinc}$ & Gay-Lussac & 6.8 .61 & 41. & $6 \cdot 121$ & 5. & $3-3 \cdot 045$ \\
\hline - Cobalt & Pronst & 8.5384 & 50 . & 5.855 & 5. & $3-2.013$ \\
\hline - Antimony & Berzulins & 6.70193 & $53 \cdot 69$ & $8 \cdot 011$ & 5 & $4-3.986$ \\
\hline - Silver & Marcet & $10 \cdot 4743$ & $135^{\circ}$ & $12 \cdot 589$ & 4. & $5-5 \cdot 13 t$ \\
\hline - Lead & Berzelins & $11 \times 29+$ & $199 \cdot 5$ & 11.538 & 7. & $8-8.036$ \\
\hline - Bismuth & Berzelius & 9.7654 & $86 \cdot 55$ & 8.843 & $8 \cdot$ & $7-7.034$ \\
\hline Copper & Chenevix & 8.845 & 40 & 4.497 & 9 . & $4-4.027$ \\
\hline - Iron & Thenard & 7.798 & $34 \cdot 5$ & 4.430 & $9 \cdot$ & $4=3.967$ \\
\hline
\end{tabular}

\section{Notices respecting New Books.}

A Dissentation on Weights and Measures, and the simplest Means of revising the British System,- - said to be from the pen of Dr. Gregory of Woolwich, and printed in the 17 th number of the British Review,-will be published in a separate pamphlet immediately.

Early in the Spring will be published by Mr. Newman, SohoSquare, Chromatics; or An Essay on the Analogy and Harmony of Colours; containiug elementary Instruction for producing Colours by Composition in all the Variety of Hues and Shades; with a new Theory of their Relations, Arrangement, and Harmony.

In this Essay the coincidences of Music will be pointed out, and the whole illustrated by coloused diagrams, \&c.

Mr. Murray's Elements of Chemical Science, second edition, with 